\title{
THE EFFECT OF VACUUM COOKING ON ENTERAL FOOD MADE FROM FRESH AND SEMI-FINISHED INGREDIENTS
}

\author{
Liene Ozola, Solvita Kampuse \\ Latvia University of Agriculture \\ lieneozola8@inbox.lv
}

\begin{abstract}
Enteral feeding also known as enteral nutrition is nutritient delivery into the stomach. Products for enteral nutrition are a specific group of products designed to provide nutrients to the human body in case of various diseases and after surgery, when the daily intake of the product is affected. Today market offers special dietetic products, which are supplemented with synthetic vitamins and minerals, which bioavailability in the body is lower than that of natural organic complexes. Therefore it is important to develop special dietetic products from natural raw materials. The aim of this study was to evaluate the effect of vacuum cooking on the content of bioactive compounds, soluble solids, $\mathrm{pH}$ and shelf life of enteral food made from fresh and semi-finished (heated) fruit and vegetable juices. For this research enteral food was made using fresh or semi-finished fruit and vegetable juices. Products were vacuum cooked in $0.02 \mathrm{MPa}$ pressure, with boiling point $67^{\circ} \mathrm{C}$, and $0.06 \mathrm{MPa}$ pressure at $79^{\circ} \mathrm{C}$, withstander for $15 \mathrm{~min}$. All samples were stored at room temperature and tested for their content of vitamin $\mathrm{C}$, total carotenoids, anthocyanins, total phenols and antioxidant activity and microbiological safety, as control untreated enteral food samples were used. The obtained data showed that samples made from semi-finished juices have higher contents of vitamin $\mathrm{C}$ and total carotenoids and anthocyanins than samples prepared from fresh juices, but this wasn't observed with content of total phenols and antiradical scavenging activity (DPPH), where the type of ingredients used for sample preparation had no significant effect.
\end{abstract}

Key words: enteral nutrition, microbial safety, total carotenoids, phenols, anthocyanins, antiradical scavenging activity.

\section{Introduction}

Enteral nutrition using oral nutrition supplements and tube feeding gives the opportunity of increasing or ensuring nutrient intake when it is inadequate. This can only be used on patients with sufficient digestion where the food can be digested and nutrients assimilated in the body of a specially prepared diet (Ozola et al., 2017; Weimann et al., 2006). Enteral feeding is a method of supplying oral food and fluids using nasogastric, gastrostomy or jejunostomy feeding, which are also referred to as enteral tube feeding (Jones et al., 2011; Ozola et al., 2017).

Depending on the intended use and specific needs of the patient, there are several types of enteral food, though most of them are synthetic it is possible to create enteral food using natural ingredients. To fully provide the necessary nutrients and at the same time the microbiological safety of the product it is needed to explore other product processing methods, that are lenient to bioactive compounds, vacuum cooking (cook-vide) is considered to be one of them.

The vacuum cooking treatments are aimed at improving the quality of coked products (IborraBernad et al., 2014). Vacuum based cooking treatments may be innovative combined techniques with high potential application on an industrial scale, this could benefit microbiological, nutritional, physicochemical and sensorial quality compared to conventional cooking methods, since the partial vacuum that is created allows cooking at lower temperature (Martinez-Hernandez et al., 2013).
To vacuum treatments such as sous-vide (SV) and cook-vide the main advantage is the absence of oxygen and the use of temperatures under $100{ }^{\circ} \mathrm{C}$, these two factors play a major role in protection of bioactive compounds, that are sensitive to temperature and can increase their degradation rate during food processing. The use of vacuum technologies could provide higher flavour retention, lower production of acrylamide and higher retention of pigments, where all these factors can lead to a better quality of the final product (IborraBernad et al., 2014; Ozola \& Kampuse, 2017).

In contrast to SV treatments cook-vide consist of cooking in boiling water below $100{ }^{\circ} \mathrm{C}$ by lowering the pressure to reach the vapour pressure of water, this method of coocking has been already used in some traditional cuisine restaurants. The low pressure is maintained during the cooking time by vacuumpump. Up to this day very few scientific studies have been found in the literature about the use of this technique on fruit and vegetable or other product treatment (Iborra-Bernad, García-Segovia, \& Martínez-Monzó, 2015; Martinez-Hernandez et al., 2013) physicochemical and structural properties of cut and cooked purple-flesh potato, green bean pods, and carrots have been studied. Three different cooking methods have been applied: traditional cooking (boiling water at 100 lu00b0C

The aim of this research was to analyse the effect of vacuum cooking on the bioactive compound content, soluble solids, $\mathrm{pH}$ and shelf life of enteral food made from fresh and semi-finished (heated) fruit and vegetable juices. 


\section{Materials and Methods}

Sample preparation

The research was carried out from January to February 2017 in Latvia University of Agriculture, Faculty of Food technology. For the purpose of this research samples of the same recipe enteral food were prepared ensuring $418.4 \mathrm{~kJ}$ intake per $161.25 \mathrm{~g}$ of product by using juices $(97.3 \%$ of total weight) from blackcurrant (Ribers nigrum), beetroot (Beta vulgaris), pumpkin from Hubbard group (Cucurbita maxima), cabbage (Brassica oleracea) and Jerusalem artichoke (Helianthus tuberosus) and whey protein, canola oil made from Brassiacaceae family of plants, cod liver oil made from fish of the Gadus genus, iodized salt. For one part of the experiment fresh juices (obtained from raw fruits and vegetables grown in organic management system), for the other part juices previously vacuum cooked (heated, semifinished) (prepared by Ltd 'KEEFA' 'Natural Food manufacturer' from the same raw material) were used (Ozola et al., 2017). Semi-finished juice samples were vacuum cooked in temperatures $73 \pm$ $5{ }^{\circ} \mathrm{C}$ under $0.05 \pm 0.01 \mathrm{MPa}$ pressure for $20 \pm 5 \mathrm{~min}$, depending on processed product, and heated up to $94{ }^{\circ} \mathrm{C}$ before packaging. Cooled juices were stored at $5 \pm 2{ }^{\circ} \mathrm{C}$.

\section{Vacuum cocking}

One average sample of each set of ingredients was made and vacuum cooked using Stephan UMC 5 vacuum kettle (Stephan Food Service Equipment $\mathrm{GmbH}$, Germany) under two modes: $0.06 \mathrm{MPa}$ pressure, product temperature during cooking reaches $79 \pm 2{ }^{\circ} \mathrm{C}$ withstanded for $15 \mathrm{~min}$; $0.02 \mathrm{MPa}$ pressure, product temperature during cooking $67 \pm 2{ }^{\circ} \mathrm{C}$ withstanded for 15 min (Ozola \& Kampuse, 2017). The processed samples were divided between 6 individually packaged $100 \mathrm{~mL}$ polypropylene (PP) bottles (Kartell, Italy) from each cooking mode.

After product processing, samples were stored at room temperature $\left(19 \pm 2{ }^{\circ} \mathrm{C}\right)$ in direct light to observe the changes of bioactive compounds content during storage. Obtained results were compared depending on the type of used ingredients for the preparation of products and the selected vacuum cooking modes. For initial comparison of the vacuum coking impact on both group samples control tests were done with samples that were not treated (Ozola et al., 2017).

The quality changes of the samples during the storage were evaluated by microbial safety, tested with the determination of total plate count, coliforms, moulds, and yeasts, determination of soluble solids content, $\mathrm{pH}$ value, vitamin $\mathrm{C}$, total carotenoids, total anthocyanins, total phenols, and antiradical activity (Ozola et al., 2017).

\section{Microbiological analyses}

Microbiological testing of enteral food was completed using $90 \mathrm{~mL}$ of $0.5 \%$ sterile peptone water solution to which $10 \mathrm{~mL}$ of enteral food was added and mixed. The mixture was pour-plated in duplicate for determination of: total plate count (TPC) according to standard LVS EN ISO 4833:2003 (Ref. No. 01-14, Sharlau, nutrient agar, incubation at $30{ }^{\circ} \mathrm{C}$ for $72 \mathrm{~h}$ ); Coliforms according to standard LVS ISO 7251:2005 (Ref. No. 401460, Sharlau ENDO agar, incubation at $37^{\circ} \mathrm{C}$ for $24 \mathrm{~h}$ ); mould fungi and yeast cells according to standard ISO 21257-2:2008 (Ref. No.01-111, MRS agar, incubation at $27^{\circ} \mathrm{C}$ for $48 \mathrm{~h}$ (yeast cells) and 5 to 7 days (mould fungi).

Microbiological safety of enteral food was evaluated according to the guidelines by Cabinet of Ministers, Latvia regulation No 461/2014 for Vegetable jams, purees and similar products which sets allowed limits for TPC at $5 \cdot 10^{3} \mathrm{CFU} \mathrm{g}^{-1}$; presence of Coliforms per $1 \mathrm{~g}$ of product is not allowed; Mould fungi and yeast cells no more than $50 \mathrm{CFU} \mathrm{g}^{-1}$ (Ozola et al., 2017).

\section{Soluble solids content and $\mathrm{pH}$}

The soluble solids content (Brix\%) was measured with digital refractometer Refracto 30GS (Mettler Toledo, Japan) using standard method ISO 2173:2003.

The identification of enteral food samples

Table 1

\begin{tabular}{|c|c|c|c|c|}
\hline \multirow{2}{*}{ Type and description of used juices } & \multicolumn{3}{|c|}{ Vacuum cooking mode } & \multirow{2}{*}{ Sample name } \\
\hline & temperature $\left({ }^{\circ} \mathrm{C}\right)$ & pressure $(\mathrm{MPa})$ & time (min) & \\
\hline \multirow{3}{*}{$\begin{array}{l}\text { Fresh juices (made from raw fruits and } \\
\text { vegetables) }\end{array}$} & \multicolumn{3}{|c|}{ untreated } & fresh \\
\hline & $67 \pm 2$ & 0.02 & 15 & I VS \\
\hline & $79 \pm 2$ & 0.06 & 15 & II VS \\
\hline \multirow{3}{*}{$\begin{array}{l}\text { Semi-finished juices (industrially vacuum } \\
\text { cooked) }\end{array}$} & \multicolumn{3}{|c|}{ untreated } & heated \\
\hline & $67 \pm 2$ & 0.02 & 15 & I VP \\
\hline & $79 \pm 2$ & 0.06 & 15 & II VP \\
\hline
\end{tabular}


Measurements were carried out in five replications. Potential of hydrogen commonly known as $\mathrm{pH}$ was measured with $\mathrm{pH}$-meter (Lutron electronic enterprise CO., Ltd., UK) using standard method LVS ISO 5542:2010. Measurements were carried out in two replications (Ozola et al., 2017).

\section{Vitamin C}

Content of vitamin $\mathrm{C}$ was determined according to iodine method (Kerch et al., 2011). Method is based on determination of Lascorbic acid, a reduced form of ascorbic acid. A sample of $25 \mathrm{~g}$ of product was poured with $100 \mathrm{~mL}$ of $6 \%$ solution of oxalic acid and homogenized for 1 minute and filtered. Then, $2 \mathrm{~mL}$ of $1 \%$ solution of starch was added to $10 \mathrm{~mL}$ of filtrate and the filtrate was titrated until change of colour, which does not disappear during $30 \mathrm{~s}$. For standardsolution of ascorbic acid $20 \mathrm{mg}$ of ascorbic acid were dissolved in $100 \mathrm{~mL}$ of the oxalic acid solution, $2 \mathrm{~mL}$ of the starch solution was added to $25 \mathrm{~mL}$ of the standard-solution and the mixture was titrated. The content of ascorbic acid mg per $100 \mathrm{~g}$ of product was calculated using formula (1) (Kerch et al., 2011; Ozola et al., 2017):

$$
C=5000 \cdot \frac{V_{\text {sample }}}{m \cdot V_{s \tan \text { dard }}}
$$

where: $\mathrm{V}_{\text {sample }}-$ volume of the iodine solution titrated in a sample, $\mathrm{mL} ; \mathrm{V}_{\text {standard }}$ - volume of the iodine solution titrated in a standard solution, $\mathrm{mL} ; \mathrm{m}-$ the amount of sample, $\mathrm{g}$.

Measurements were carried out in four replications.

\section{Total Carotenoids}

For total carotenoid determination a spectrophotometric (UV/VIS spectrophotometer Jenway 6705 (Bibby Scientific Ltd., UK)) method described by (Kampuse et al., 2015) was used at wavelength of $440 \mathrm{~nm}$. The content of carotenoids (mg $100 \mathrm{~g}^{-1}$ ) was calculated in four replications (Ozola et al., 2017).

\section{Total anthocyanins}

Total anthocyanin content was determined by spectrophotometric method according to (Kerch et al., 2011), detected on spectrophotometer Jenway 6705 at wavelength of $540 \mathrm{~nm} .20 \mathrm{~g}$ of sample was doused with $40 \mathrm{~g}$ of ethanol and $1.5 \mathrm{M} \mathrm{HCl}$ solution $(85: 15$ by volume) and homogenized for $1 \mathrm{~min}$. Then the sample was filtered, and light absorption at $540 \mathrm{~nm}$ was detected with spectrophotometer. Sample was diluted until absorption coefficient was between 0.6 and 0.8 . Content $\mathrm{mg}$ per $100 \mathrm{~g}$ was calculated with the equation (2) (Ozola et al., 2017):

$$
C=\frac{A \cdot v \cdot d \cdot 1000}{980 \cdot m}
$$

where: A - absorption coefficient; v - volume of the extraction (90); $\mathrm{d}$ - dilution; $\mathrm{m}$ - sample weight in $\mathrm{g}$ (20).

Measurements were carried out in two replications.

\section{Total phenol content}

The detection of total phenol content was done according to the Folin- Ciocalteu method (Yu et. al., 2003)2-diphenyl-1-picrylhydrazyl radical (DPPH u2022 with modifications: to $0.5 \mathrm{~mL}$ of extracted sample add $2.5 \mathrm{~mL}$ of $0.2 \mathrm{~N}$ Folin-Ciocalteu reagent, that has been diluted ten times with distilled water; after $5 \mathrm{~min}$ add $2.0 \mathrm{~mL}$ of $7.5 \% \mathrm{NaCO}_{3}$; the resulting solution was mixed and allowed to stand for $30 \mathrm{~min}$ at $18 \pm 1{ }^{\circ} \mathrm{C}$ in a dark place; absorption was read at $760 \mathrm{~nm}$ using JENWAY 6300 (Banoworld Scientific Ltf., UK) spectrophotometer (Priecina \& Karklina, 2014) (Ozola et al., 2017).

Measurements were carried out in six replications from two separately weighed samples.

\section{Antiradical scavenging activity (DPPH)}

The antiradical scavenging activity of extracts was determined according to (Yu et al., 2003)2-diphenyl1-picrylhydrazyl radical (DPPH $\backslash$ u2022 with modifications: to $0.5 \mathrm{~mL}$ of extracted sample $3.5 \mathrm{~mL}$ freshly made DPPH solution was added; the mixture was shaken and kept in the dark place at $18 \pm 1{ }^{\circ} \mathrm{C}$ for $30 \mathrm{~min}$; absorbance was measured at $517 \mathrm{~nm}$ using JENWAY 6300 Spectrophotometer (Ozola et al., 2017; Priecina \& Karklina, 2014).

Measurements were carried out in six replications from two separately weighed samples.

\section{Statistical analysis}

The obtained data was processed using 'Microsoft Office Excel' 2007 version, differences between the results were analysed using ANOVA: one and two-factor with replications. The obtained results are presented as their mean with standard error. Differences among results were considered to be significant if pvalue $<\alpha_{0.05}$ (Ozola et al., 2017).

\section{Results and Discussion}

Effect of vacuum cooking and storage on microbial safety

All samples including control (without vacuum cooking) were microbiologically tested before storage, vacuum treated enteral food samples were also tested during storage. No coliforms and mould fungi were found in evaluated samples. The initial results (Table 2) on enteral food made from fresh juices show 
that vacuum cooking can decrease the total plate count and yeast cell count, but the used treatment modes have not been successful for creating microbiologically safe products, this information does not coincide with previously made research on vacuum cooking mode application on pumpkin-guilder rose sauces (Ozola \& Kampuse, 2017) and other author findings, that suggest vacuum-based cooking generally induces higher microbial reduction. Enteral food samples made from semi-finished juices show a higher microbial safety before storage however only storing them for 7 days already show some signs of spoilage for sample I VP (cooked at $67^{\circ} \mathrm{C}, 0.02 \mathrm{MPa}$ pressure) and in 14 days sample II VP (cooked at $79{ }^{\circ} \mathrm{C}$, $0.06 \mathrm{MPa}$ ). Temperatures and pressure modes used in this research should be sufficient for minimizing the yeast cell count in product, but the obtained data suggest the opposite. These findings could be affected and be a direct response to contamination from air or packaging as the product filling process was done in open space.

Martinez-Hernandez et al., 2013 in their research vacuum boiled Kailan-hybrid broccoli (Brassica oleracea $)$ at 0.9 bar $(0.01 \mathrm{MPa})$ where the boiling point was reached at $54{ }^{\circ} \mathrm{C}$ and the microbial testing showed no signs of yeasts and moulds, however some mesophilic, psychrophilic and enterobacteria still had remained. The microbial testing showed that the most effective cooking method was pressure cooking and sous vide (Martinez-Hernandez et al., 2013).

NA-not analysed; Fresh- enteral food made from fresh juices, untreated; I VS- enteral food made from fresh juices, vacuum cooked at $0.02 \mathrm{MPa}$ pressure; II VS- enteral food made from fresh juices, vacuum cooked at $0.06 \mathrm{MPa}$ pressure; Heated- enteral food made from semi-finished juices, untreated; I VSenteral food made from semi-finished juices, vacuum cooked at $0.02 \mathrm{MPa}$ pressure; II VS- enteral food made from semi-finished juices, vacuum cooked at $0.06 \mathrm{MPa}$ pressure.

Samples made from fresh juices after vacuum cooking exceed the allowed yeast cell count
$50 \mathrm{CUF} \mathrm{g}^{-1}$ (Table 2) and are considered to be unsuited for further use and testing. After storing the rest of enteral food samples for 7 days sample cooked at $0.02 \mathrm{MPa}$ was determined to be unsuitable accordingly to the guidelines by Cabinet of Ministers, Latvia regulation No 461/2014 for 'Vegetable jams, purees and similar products' for further testing by exceeding both total plate count $6.5 \cdot 10^{3} \mathrm{CFU} \mathrm{g}^{-1}$ (allowed TPC $\left.5 \cdot 10^{3} \mathrm{CUF}^{-1}\right)$ and yeast count $1.5 \cdot 10^{2} \mathrm{CFU} \mathrm{g}^{-1}$. Sample II VP, which was processed at $0.02 \mathrm{MPa}$, boiling point $67^{\circ} \mathrm{C}$, after storing for 14 days started to show some microbial spoilage, but signs of microbial fermentation was determined only after additional week, when this sample also was presumed to be unsuitable.

Effect of vacuum cooking and storage on soluble solids and $\mathrm{pH}$

Soluble solids and product $\mathrm{pH}$ didn't show any significant differences and changes between the enteral foods after treatment, also no significant differences were noticed during storage or between the types of used juices for enteral food preparation. On average the soluble solids content was $11.4 \pm 0.2$ Brix $\%$ and the $\mathrm{pH}$ to samples made from fresh juices was $\mathrm{pH} 5.00$ \pm 0.03 , but from semi-finished $\mathrm{pH} 4.61 \pm 0.04$.

Effect of vacuum cooking and storage on bioactive compounds (vitamin $C$, total carotenoids, total anthocyanins, total phenols and DPPH)

The obtained data on vitamin $\mathrm{C}$, total carotenoids and anthocyanin content in enteral food samples is given in Table 3 . The data show a significant difference $(p<0.05)$ in content of vitamin $C$ between the samples depending on what type of juices were used for the preparation. Samples from fresh juices showed overall higher content of vitamin $\mathrm{C}$, than samples made from semi-finished juices, but no significant difference was detected between the treatment methods or depending on the storage time.

The content of total carotenoids (Table 3) showed significant changes not only on type of juices used

Total plate and yeast cell count in enteral food made from natural juices (CUF g $\left.\mathbf{g}^{-1}\right)$

Table 2

\begin{tabular}{|l|c|c|c|c|c|c|}
\hline \multirow{2}{*}{ Sample } & \multicolumn{3}{|c|}{ Total plate count } & \multicolumn{3}{c|}{ Yeast cell count } \\
\cline { 2 - 7 } & before storage & day 7 & day 14 & before storage & day 7 & day 14 \\
\hline Fresh & $1.3 \cdot 10^{3}$ & NA & NA & $3.4 \cdot 10^{2}$ & NA & NA \\
\hline I VS & $2.9 \cdot 10^{2}$ & NA & NA & $2.4 \cdot 10^{2}$ & NA & NA \\
\hline II VS & $1.6 \cdot 10^{2}$ & NA & NA & $1.2 \cdot 10^{2}$ & NA & NA \\
\hline Heated & $<10$ & NA & NA & $<10$ & NA & NA \\
\hline I VP & $<10$ & $6.5 \cdot 10^{3}$ & NA & $<10$ & $1.5 \cdot 10^{2}$ & NA \\
\hline II VP & $<10$ & $<10$ & 59 & $<10$ & $<10$ & 47 \\
\hline
\end{tabular}




\section{Content of vitamin $\mathrm{C}$, total carotenoids and total anthocyanins in} enteral food made from natural juices $\left(\mathrm{mg} 100 \mathrm{~g}^{-1}\right)$

\begin{tabular}{|l|l|c|c|c|}
\hline \multicolumn{1}{|c|}{ Sample } & \multicolumn{1}{|c|}{ Storage time } & Vitamin C & Total carotenoids & Total anthocyanins \\
\hline Fresh & before storage & $24.99 \pm 3.46$ & $0.44 \pm 0.00$ & $1.50 \pm 0.07$ \\
\hline I VS & before storage & $24.11 \pm 2.97$ & $0.41 \pm 0.01$ & $1.59 \pm 0.02$ \\
\hline II VS & before storage & $22.29 \pm 1.21$ & $0.32 \pm 0.01$ & $1.27 \pm 0.01$ \\
\hline \multirow{2}{*}{ Heated } & before storage & $21.37 \pm 1.22$ & $0.43 \pm 0.02$ & $2.45 \pm 0.15$ \\
\hline \multirow{3}{*}{ I VP } & before storage & $19.33 \pm 1.12$ & $0.43 \pm 0.01$ & $2.17 \pm 0.01$ \\
\cline { 2 - 5 } & day 7 & $18.15 \pm 2.06$ & $0.37 \pm 0.01$ & $1.84 \pm 0.04$ \\
\hline \multirow{3}{*}{ II VP } & before storage & $19.13 \pm 1.49$ & $0.44 \pm 0.01$ & $1.65 \pm 0.13$ \\
\cline { 2 - 5 } & day 7 & $18.24 \pm 2.00$ & $0.37 \pm 0.01$ & $1.49 \pm 0.00$ \\
\cline { 2 - 5 } & day 14 & $16.25 \pm 1.26$ & $0.35 \pm 0.00$ & $1.41 \pm 0.04$ \\
\hline
\end{tabular}

for enteral foods, but also samples made from fresh juices have been affected more by the vacuum cooking modes. Samples made from fresh juices show higher decrees in content of total carotenoids and anthocyanins when the vacuum cooking pressure and temperature is higher, opposite to vacuum cooking samples at $0.02 \mathrm{MPa}$ pressure, when the content of total carotenoids and anthocyanins was typically closer to the control samples. Semi-finished juice enteral food samples showed a $13 \%$ decrees in content of total carotenoids during storage when it significantly dropped after storing for 7 days in sample I VP $0.43 \pm$ $0.0 \mathrm{mg} 100 \mathrm{~g}^{-1}$ before storage to $0.37 \pm 0.01 \mathrm{mg} 100 \mathrm{~g}^{-1}$ day 7 and in sample I VP $0.44 \pm 0.01 \mathrm{mg} 100 \mathrm{~g}^{-1}$ before storage to $0.35 \pm 0.00 \mathrm{mg} 100 \mathrm{~g}^{-1}$ day 14 .

Changes of total anthocyanin content depending on the used vacuum cooking mode was also noticed in semi-finished samples, the highest total anthocyanin content was in sample I VP $(0.02 \mathrm{MPa})$ made from semi-finished juices $2.17 \pm 0.01 \mathrm{mg} 100 \mathrm{~g}^{-1}$, but the lowest in sample II VS (0.06 MPa) made from fresh juices $1.27 \pm 0.01 \mathrm{mg} 100 \mathrm{~g}^{-1}$. These coincide with other author findings about better colour retention in products by using vacuum based treatments compared to conventional cooking which does suggest that application of higher temperatures can significantly decrees the content of carotenoids and anthocyanins that often are responsible for the natural colour of fruits and vegetables (Iborra-Bernad et al., 2015)physicochemical and structural properties of cut and cooked purple-flesh potato, green bean pods, and carrots have been studied. Three different cooking methods have been applied: traditional cooking (boiling water at 100 lu00b0C.

Fresh- enteral food made from fresh juices, untreated; I VS- enteral food made from fresh juices, vacuum cooked at $0.02 \mathrm{MPa}$ pressure; II VS- enteral food made from fresh juices, vacuum cooked at $0.06 \mathrm{MPa}$ pressure; Heated- enteral food made from semi-finished juices, untreated; I VS- enteral food made from semi-finished juices, vacuum cooked at $0.02 \mathrm{MPa}$ pressure; II VS- enteral food made from

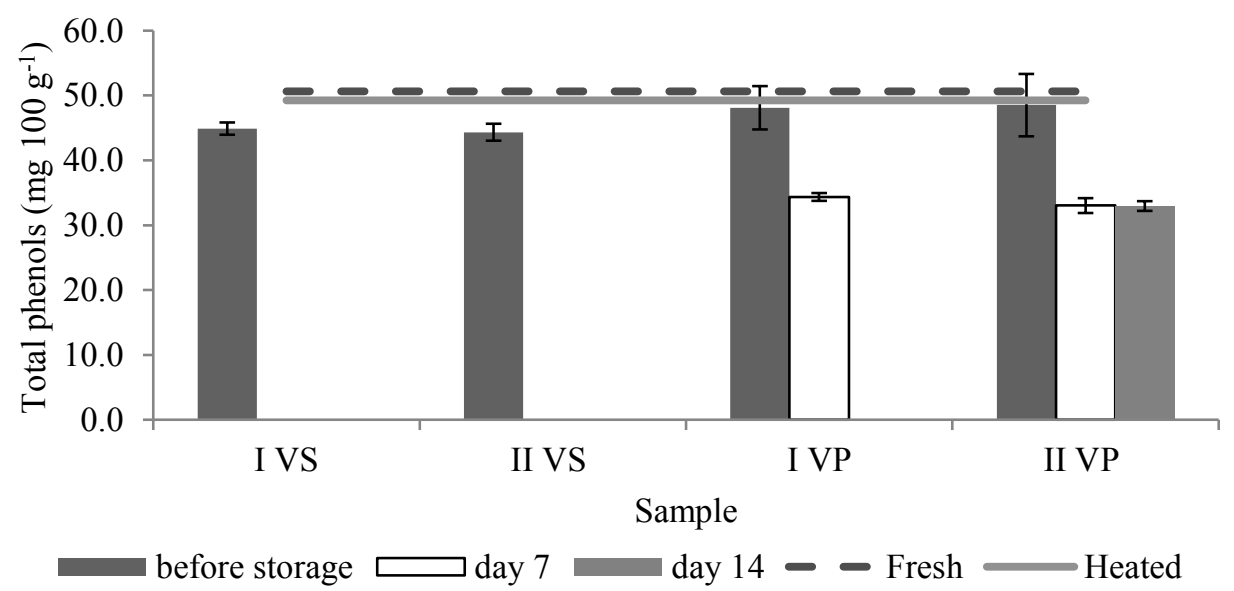

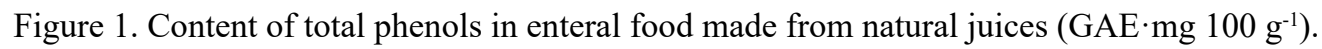




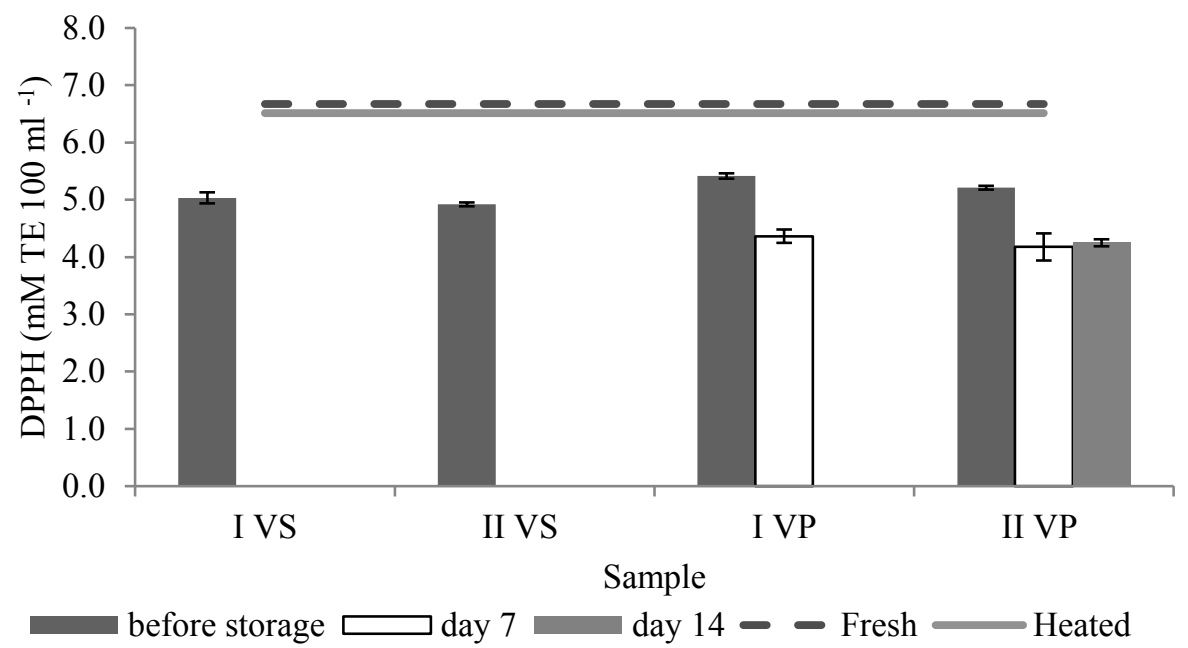

Figure 2. Contents of antiradical activity (DPPH) in enteral food made from natural juices (mM TE $100 \mathrm{ml}^{-1}$ ).

semi-finished juices, vacuum cooked at $0.06 \mathrm{MPa}$ pressure.

Total phenol content (Figure 1) in enteral food samples show no significant difference $(\mathrm{p}<$ 0.05 ) between the type of juices used for sample preparation, however slightly higher total phenol content was noticed in samples made from semifinished juices. After storing samples for 7 days a $30 \%$ loss of total phenols was detected to samples made from semi finished juices, sample I VP 48.11 $\pm 3.34 \mathrm{GAE} \cdot \mathrm{mg} 100 \mathrm{~g}^{-1}$ before storage, to $34.36 \pm$ $0.60 \mathrm{GAE} \cdot \mathrm{mg} 100 \mathrm{~g}^{-1}$ at day 7 and to sample II VP $48.52 \pm 4.81 \mathrm{GAE} \cdot \mathrm{mg} 100 \mathrm{~g}^{-1}$ before storage, to 39.96 $\pm 0.75 \mathrm{GAE} \cdot \mathrm{mg} 100 \mathrm{~g}^{-1}$ day 14 .

Fresh- enteral food made from fresh juices, untreated; I VS- enteral food made from fresh juices, vacuum cooked at $0.02 \mathrm{MPa}$ pressure; II VS- enteral food made from fresh juices, vacuum cooked at $0.06 \mathrm{MPa}$ pressure; Heated- enteral food made from semi-finished juices, untreated; I VS- enteral food made from semi-finished juices, vacuum cooked at $0.02 \mathrm{MPa}$ pressure; II VS- enteral food made from semi-finished juices, vacuum cooked at $0.06 \mathrm{MPa}$ pressure.

The antiradical activity (Figure 2) of enteral food samples contrary to total phenol content showed a significant difference $(p<0.05)$ between the vacuum cooking modes used in this research and slight differences by type of juices used for sample preparation. The most noticeable changes in DPPH were detected during storage where on average a $19 \%$ decrease of DPPH was noticed after 7 days of sample storage.

Fresh- enteral food made from fresh juices, untreated; I VS- enteral food made from fresh juices, vacuum cooked at $0.02 \mathrm{MPa}$ pressure; II VS- enteral food made from fresh juices, vacuum cooked at $0.06 \mathrm{MPa}$ pressure; Heated- enteral food made from semi-finished juices, untreated; I VS- enteral food made from semi-finished juices, vacuum cooked at $0.02 \mathrm{MPa}$ pressure; II VS- enteral food made from semi-finished juices, vacuum cooked at $0.06 \mathrm{MPa}$ pressure.

The differences in DPPH depending on vacuum cooking mode could be impacted by the differences in content of vitamin $\mathrm{C}$ and total anthocyanins, which showed a bigger retention in samples cooked under lower temperature and higher pressure $\left(67{ }^{\circ} \mathrm{C}, 0.02 \mathrm{MPa}\right.$ pressure) for samples made from semi-finished juices. To enteral food samples made from fresh juices also total carotenoid content was significantly different depending on the used vacuum cooking mode.

The findings of this research partly coincide with previous research done on vacuum cooking modes, where pumpkin-guelder rose sauce samples cooked under vacuum didn't show any significant differences in bioactive compound content depending on the used vacuum treatment (Ozola \& Kampuse, 2017). However this research showed some coincidences with enteral food samples made from semi-finished juices.

The overall research on this particular thermal processing method is rather deficient. Due to the lack of research on this subjeckt it is difficult to make a full study analysis and to fully evaluate the efficiency of the vacuum cooking process compared to other thermal treatments.

\section{Conclusions}

The findings of this research coincide with some of the few researches that have been done on this subject, comparing to conventional cooking vacuum cooking does show a higher retention on total phenol content, DPPH and carotenoids and anthocyanins, but additional research needs to be done, to provide 
sufficient amount of data on vacuum cooking modes and efficiency it has on bioactive compounds and microbial safety of products.

The obtained data also showed no significant difference in total phenol content and DPPH depending on type of juices used as ingredients, but showed better results in content of total carotenoids and anthocyanins with enteral food samples made from semi-finished juices.

Initial results show that vacuum cooking with following of hot filling wasn't sufficient enough to provide microbiologically safe products made from fresh juices, but using semi-finished ingredients the shelf life of these products cannot exceed 14 days.

\section{Acknowledgements}

Program 'Scientific Capacity Building LUA' project A05-06 'Development of special dietary foods with high bioavailability'

\section{References}

1. Iborra-Bernad, C., García-Segovia, P., \& Martínez-Monzó, J. (2015). Physico-Chemical and Structural Characteristics of Vegetables Cooked Under Sous-Vide, Cook-Vide, and Conventional Boiling. Journal of Food Science, 80(8), E1725 - E1734. DOI: 10.1111/1750-3841.12950.

2. Iborra-Bernad, C., Tárrega, A., García-Segovia, P., \& Martínez-Monzó, J. (2014). Comparison of Vacuum Treatments and Traditional Cooking Using Instrumental and Sensory Analysis. Food Analytical Methods, 7(2), 400 - 408. DOI: 10.1007/s12161-013-9638-0.

3. Jones, L., Watling, R.M., Wilkins, S., \& Pizer, B. (2011). Cochrane Review: Nutritional support in children and young people with cancer undergoing chemotherapy. Evidence-Based Child Health: A Cochrane Review Journal, 6(4), 1236 - 1311. DOI: 10.1002/ebch.812.

4. Kampuse, S., Ozola, L., Straumite, E., \& Galoburda, R. (2015). Quality Parameters Of Wheat Bread Enriched With Pumpkin (Cucurbita Moschata) By-Products. Acta Universitatis Cibiniensis. Series E: Food Technology, 19(2), 3 - 14.

5. Kerch, G., Sabovics, M., Kruma, Z., Kampuse, S., \& Straumite, E. (2011). Effect of chitosan and chitooligosaccharide on vitamin $\mathrm{C}$ and polyphenols contents in cherries and strawberries during refrigerated storage. European Food Research and Technology, 233(2), 351 - 358. DOI: 10.1007/s00217-011-1525-6.

6. Latvia Cabinet of Ministers (2014) Prasības pārtikas kvalitātes shēmām, to ieviešanas, darbības, uzradzības un kontroles kārtība (Requrements for food quality schemes, their implementation, operation, monitoring and control arrangements) Regulations of Cabinet of Ministers No. 461. Riga: Latvia Government Publishing Service. Retrieved January 15, 2017, from: https://ikumi.lv/ta/id/277380-grozijumi-ministrukabineta-2014-gada-12-augusta-noteikumos-nr-461-prasibas-partikas-kvalitates-shemam-to-ieviesanasdarbibas. (in Latvian).

7. Martinez-Hernandez, G.B., Artes-Hernendez, F., Colares-Souza, F., Gomez, P.A., Garcia-Gomez, P., \& Artes-Hernendez, F. (2013). Innovative Cooking Techniques for Improving the Overall Quality of a KailanHybrid Broccoli. Food and Bioprocess Technology, 6(8), 2135 - 2149. DOI: 10.1007/s11947-012-0871-0.

8. Ozola, L., \& Kampuse, S. (2017). The influence of heat treatment methods to the nutrition composition of guelder rose (Viburnum opulus)- pumpkin souces. In 2nd International Conference Nutrition and Health, 5 - 7 October 2016. Proceedings of the Latvian Academy of Sciences. Section B. Natural, Exact, and Applied Sciences. Article in press.

9. Ozola, L., Kampuse, S., \& Galoburda, R. (2017). The effect of high-pressure procesing on enteral food made from fresh or semi-finished ingredients. In 11th Baltic Conference on Food Science and Technology (pp. 80 - 85). Jelgava: Latvia University of Agriculture. DOI: 10.22616/foodbalt.2017.008.

10. Priecina, L., \& Karklina, D. (2014). Natural Antioxidant Changes in Fresh and Dried Spices and Vegetables. International Journal of Biological, Biomolecular, Agricultural, Food and Biotechnological Engineering, 8(5), 492 - 496. Retrieved January 15, 2017, from: http://waset.org/publications/9998308/ natural-antioxidant-changes-in-fresh-and-dried-spices-and vegetables.

11. Weimann, A., Braga, M., Harsanyi, L., Laviano, A., Ljungqvist, O., Soeters, P., ... Vestweber, K.H. (2006). Guidelines on Enteral Nutrition: Surgery including Organ Transplantation. Clinical Nutrition, 25, $224-$ 244. DOI: 10.1016/j.clnu.2006.01.015.

12. Yu, L., Perret, J., Harris, M., Wilson, J., \& Haley, S. (2003). Antioxidant Properties of Bran Extracts from “Akron” Wheat Grown at Different Locations. Journal of Agricultural and Food Chemistry, 51(6), 1566 - 1570. DOI: 10.1021/jf020950z. 